\title{
Allogeneic CD34-positive Enriched Peripheral Blood Stem Cells
}

National Cancer Institute

\section{Source}

National Cancer Institute. Allogeneic CD34-positive Enriched Peripheral Blood Stem Cells. NCl Thesaurus. Code C160626.

A preparation of allogeneic CD34+ selected peripheral blood stem cells (PBSCs) that can potentially be used for immune reconstitution purposes. Upon administration of the allogeneic CD34-positive enriched PBSCs after a hematopoietic cell transplantation $(H C T)$, these cells may provide memory $T$-cell $(T \mathrm{~m})$ recovery and potentially prevent viral infections. They potentially reduce the occurrence of graft-versus-host disease (GvHD) without increasing the risk of graft failure or poor graft function. 